\title{
D The Consolidation of the White Southern Congressional Vote
}

\author{
CHARLES S. BULLOCK, III, UNIVERSITY OF GEORGIA \\ DONNA R. HOFFMAN, UNIVERSITY OF NORTHERN IOWA \\ RONALD KEITH GADDIE, UNIVERSITY OF OKLAHOMA
}

\begin{abstract}
This article explores the initial desertion and continued realignment of about one-sixth of the white voters in the South who, until 1994, stood by Democratic congressional candidates even as they voted for Republican presidential nominees. Prior to 1994, a sizable share of the white electorate distinguished between Democratic congressional and presidential candidates; since 1994 that distinction has been swept away. In 1992, a majority of white southern voters was casting their ballot for the Democratic House nominee; by 1994, the situation was reversed and 64 percent cast their ballot for the Republican. Virtually all categories of voters increased their support of Republican congressional candidates in 1994 and the following elections further cement GOP congressional support in the South. Subsequent elections are largely exercises in partisanship, as the congressional votes mirror party preferences. Republicans pull nearly all GOP identifiers, most independents, and a sizeable minority of Democratic identifiers. Democrats running for Congress no longer convince voters that they are different from their party's presidential standard bearers-a group that has consistently been judged unacceptable to overwhelming proportions of the southern white electorate.
\end{abstract}

If the trend continues, the voting loyalty of southern white Democrats to House candidates will soon be on a par with that toward Democratic presidential candidates (Stanley 1988: 77).

In the long run, however, the realignment appeared certain to continue to work its way steadily downward through the political levels-from presidential voting to statewide voting to local voting ... (Sundquist 1983: 375).

$\mathrm{R}$ epublican gains in the South have come slowly and inconsistently. The GOP became the party of choice in presidential elections in the Rim South in the 1950s and achieved similar status in the Deep South a decade later. In 1972 for the first time in the modern era, Republicans swept the South's Electoral College votes, a pattern that, with one exception, recurred throughout the 1980s and again in 2000. ${ }^{1}$

Yet for 30 years after Barry Goldwater became the first GOP presidential nominee to win the Deep South, carrying seven Republicans into Congress on his coattails, southerners voted heavily for conservative Republican and independent presidential candidates, while returning large

\footnotetext{
${ }^{1}$ Jimmy Carter carried his home state, Georgia, in 1980. Otherwise, the South voted consistently for GOP presidential nominees during the 1980s. The South is defined as the eleven secession states.

NOTE: An earlier version of this study was presented at the annual meeting of the American Political Science Association, Boston, August 28-September 1, 2002. The data used in this analysis were provided by the Inter-University Consortium for Political and Social Research which bears no responsibility for the interpretations presented here.
}

Political Research Quarterly, Vol. 58, No. 2 (June 2005): pp. 231-243 numbers of Democrats to Congress and state legislatures. Then, in 1994, southern white support for Republican candidates surged to record levels enabling the GOP to achieve majority status in the region's U.S. Senate and House delegations, and make substantial gains in southern state legislatures (Black and Black 2002).

This study seeks to identify the voters who deserted Democratic congressional candidates in 1994, and determine whether this profile continued as part of the sustained GOP congressional majority in the South after 1994. Was there an across-the-board shift to the GOP or were some voters particularly attracted to Republican candidates? Contemporary analyses focused on angry white males and Christian fundamentalists as fueling the GOP upsurge. More generally, the 1994 results were interpreted as a rebuke to President Clinton and his health care initiatives. After identifying those whites most prone to change to the GOP, we offer reasons behind the shift. Since Democratic defectors have been overwhelmingly white, we focus on that group and what happened in 1994 and subsequent elections.

\section{The Setting}

Before 1998 the president's party invariably lost ground in mid-term elections. That alone augured for GOP gains in 1994. Republicans had made modest gains in the South in 1962, 1966, and 1978, the three most recent mid-term elections when a Democrat held the White House. The exceptional 16-seat southern shift to the GOP in 1994, constituted more seats than Republicans had gained in the three previous Democratic mid-terms combined. GOP gains were also out-of-line with expectations from retirement slumps, that had generally worked against Republican gains (Gilmour and Rothstein 1993; Gaddie 1997). 
$\equiv$ FIGURE 1

Trend in White Voting for US House And President, 1980-2000

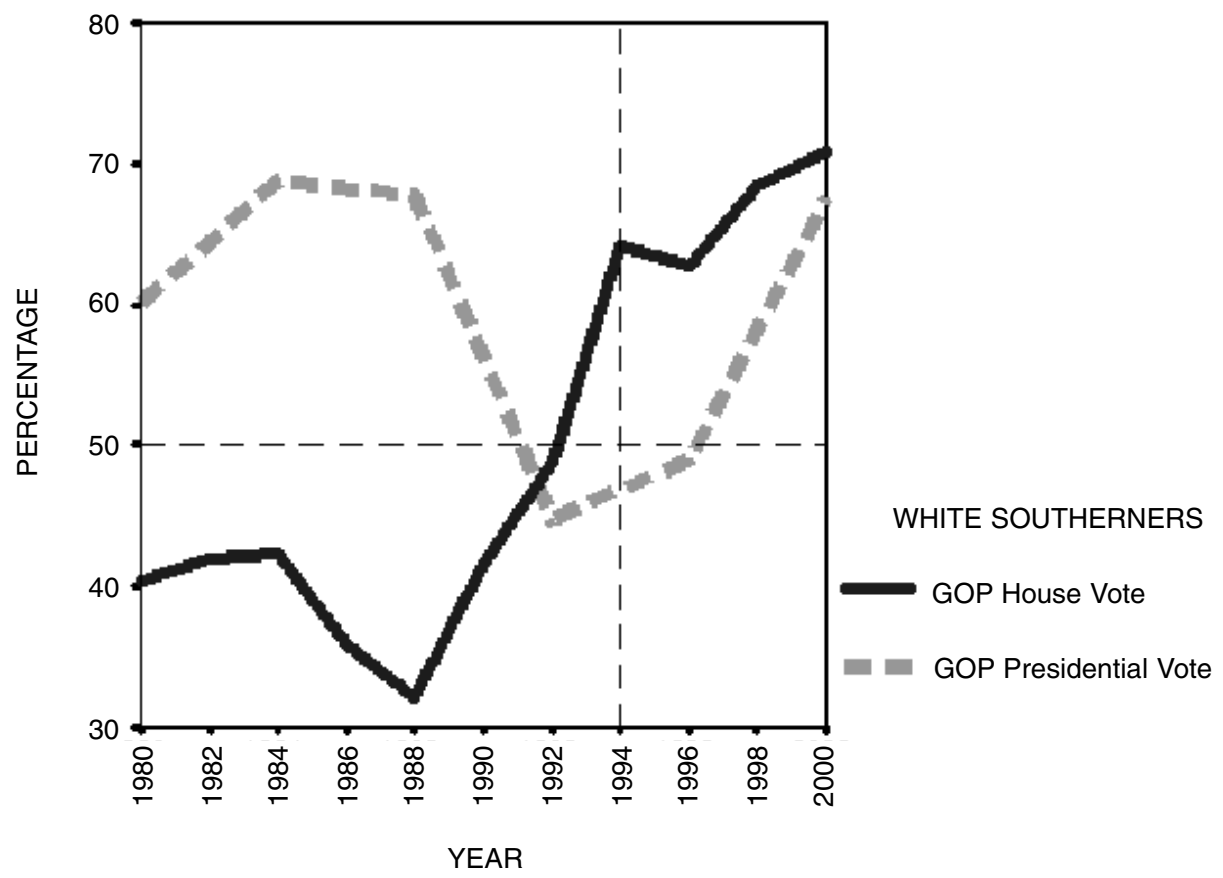

The 1994 seat shift stemmed from a remarkable change in the voting behavior of white southerners. For years, Democrats had attracted a fairly consistent share of the vote in southern House elections. According to exit polls, Democratic congressional candidates averaged 49 percent support among whites from 1980-92 (New York Times 1992). Across those seven elections, Democratic success ranged from a high of 55 percent in 1982 to a low of 45 percent of the white vote in 1984. The success in 1982 was an outlier with the other six elections showing white support between 45 and 50 percent. Exit poll estimates showed Democrats getting at least half the white vote in mid-term elections when Republicans held the White House but averaging 47 percent in presidential years, and they did no better in Clinton's initial election than the average for the three Republican presidential successes.

ANES data in Figure 1 show Democrats performing better than in exit polls among southern white voters during the 1980-1992 period. In none of these seven elections did a majority of southern white voters support Republicans for Congress. Support for GOP nominees ranged from a low of 32.2 percent in 1988 to a high of 48.4 percent in 1992 . The average level of white support for Democrats during this period was a comfortable 59.6 percent.

Despite frequent differences prior to 1992, ANES and exit poll estimates agree that 1994 was disastrous for southern Democrats. Exit polls reported that Democrats managed just 35 percent of the white vote, a level of success (failure) matched in 1996, 1998, and 2000. The 1994 collapse in white support for Democratic congressional candidates put it on par with that of their party's presidential candidates since 1980. In 1992, Bill Clinton attracted 34 percent of the southern white vote in a three-way contest, only two points above Michael Dukakis' showing in 1988. Even the flame out of the Perot meteor in 1996 did little to propel southern whites toward the Democratic party as just 36 percent of them backed Clinton's re-election bid. The ANES approximates the exit poll figures and shows Democratic nominees reduced to 35.8 percent in 1994. ANES data show the Democrats' disastrous collapse continued for the balance of the decade. About 64 percent of whites cast GOP congressional ballots in 1996, and in 1998 and 2000 the GOP share of white ballots surged toward 70 percent.

\section{PARTISAN INCONSISTENCY}

The uncanny ability of Democratic congressional nominees to retain their positions and even to pass seats on to successors has triggered journalistic comment and scholarly research. From a study of six special elections held across the South in the 1980s and 1990s, James Glaser (1996) concludes that Democrats recruited better candidates. However, Gaddie and Bullock (2000) find that candidate experience actually militated against Republican success in open seats in the South in 1994, underscoring the limits of the recruitment hypothesis in explaining GOP gains. Also the ideological contrast between candidates for southern House seats tended to be less stark than in presidential elections where a liberal Democrat often faced a conservative Republican. Congressional contests often featured a conservative 
$\equiv$ FIGURE 2

Percent of Total White Vote where Ballot was Split (Republican President/Democratic House Candidate)

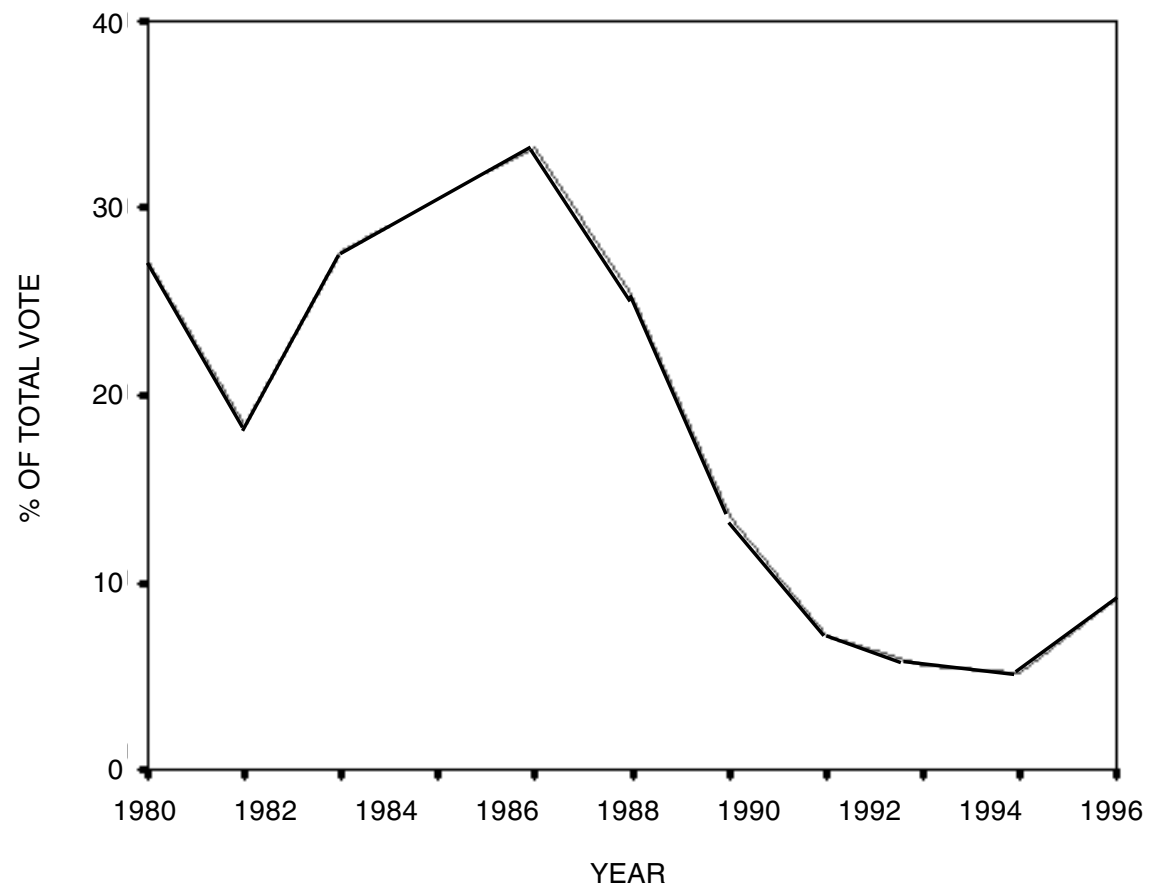

Democrat opposed by an even more conservative Republican. As Black and Black (1987) observe, Democrats have been difficult to dislodge when they run moderate conservatives or conservative moderates.

Explanations not unique to the South may also help account for the halting progress made by the GOP. Perhaps some southern voters, like those in other regions, favored Republican presidential candidates because of their economic conservativism and national defense postures while supporting Democrats for Congress because of their ability to secure benefits for the district (Jacobson 1990).

Regardless of the explanation, until 1994, many southern white voters distinguished between Democratic congressional and presidential candidates. Recently that distinction has mattered for far fewer voters. Figure 2 illustrates the incidence of ticket splitting. In 1988, fully one-third of the southern, white electorate cast a ballot for Bush for president but a Democrat for the House. By 1996, however, the ticketsplitting tendencies had declined dramatically and accounted for fewer than one voter in ten. The figure also shows partisan inconsistency in off-years, as determined by ANES asking respondents who they supported in the previous presidential election, that tracks closely with split ticket incidence in recent presidential elections.

\section{Research Design}

As a first step toward understanding the massive drop in support for Democratic House candidates among white voters, we identify the components of the southern electorate that experienced the greatest shift toward the GOP. We consider demographic characteristics of white southern voters such as gender, income level, education, and age. We also examine behavioral characteristics including partisan identification and ideology. We explore the impact of attitudinal factors associated with the evaluation of candidates and issues. These factors include both congressional and presidential approval, health care and racial policy attitudes, as well as opinions about Christian fundamentalists and homosexuals serving in the military.

Who?

Gender differences in voting behavior have plagued Republican efforts in recent years with men more likely than women to support Republicans. The GOP surge in 1994 has been attributed to mobilization of angry white males. Exit polls challenge that interpretation since they showed 68 percent of the region's white males but also 59 percent of the women backing the GOP in House contests (Balz and Brownstein 1996: 208). Alternatives that could account for the growth in GOP support witnessed in 1994 are (1) both genders move toward the GOP at similar rates thereby maintaining existing gender differences or (2) the gender gap shrank as southern white women became more Republican in 1994 while their brothers, fathers, and sons changed little in their partisan preferences. Miller and Shanks (1996) observed that the trend of white southern females toward the GOP arrested in 1980, while the men kept going toward the GOP. 
Class is a second element that has frequently differentiated partisans, with Republicans having greater appeal among the better educated and more affluent. The GOP in the South has striven to shake its country club image, and where it has succeeded it attracts support from a wide range of income and education groups. Senator Jesse Helms (RNC), who ran especially well among the "Jessecrats" in the tobacco-growing eastern part of his state, won over bluecollar workers. Did the southern Democrats' collapse result from the migration of downscale whites to the GOP so as to mute class differences in voting behavior? Exit polls suggest that working class voters who have been a Democratic mainstay nationwide shifted to the GOP in the South in 1994 (Balz and Brownstein 1996: 347). If this is accurate then the relationship between income and support for Republicans may be weakening as the GOP attracts lower income voters.

Education is another indicator of class that has been linked to partisan voting in the South. While the earliest GOP breakthroughs in the South came among the college educated, Aistrup (1989) recognized Republican efforts among the less well educated. These efforts paid dividends as less educated whites have become increasingly likely to vote for the GOP (Black and Black 1987: 246-249; Nadeau and Stanley 1992).

Some scholars identify generational replacement as a major source of Republican growth in the South (Beck 1977; Farah and Norpoth 1986; Stanley 1988; Nadeau and Stanley 1992). While younger voters have become more supportive of GOP candidates, their parents, and especially their grandparents, hesitated to forsake the party of their ancestors. Young voters, who grew up with Ronald Reagan as their image of the chief executive and their sole first-hand recollection of a Democrat in the White House being the failed presidency of Jimmy Carter, often provided enthusiastic support for Republican candidates up and down the ticket. Older southern voters proved more reliable Democrats, either because of recollections of Franklin Roosevelt or Harry Truman, or because of personal ties to incumbent Democratic officeholders for state and local offices. Several studies see a weakening of generational differences beginning with the Reagan era (Black and Black 1987: 246-44). Petrocik (1987) reports few or no generational differences in the patterns of partisan change in the South. The old as well as the young are becoming Republicans. Wolfinger and Hagen (1985) and Parker (1988) also observe a decline during the 1980s in differences across generations in support for the GOP. To be explored here is whether any age groups shifted dramatically to the GOP in 1994 or whether various groups moved at similar rates.

Voters who identify with neither party provide another possible source of GOP support. Political scientists have found that the growth of southern independents resulted from conservative whites abandoning the Democratic Party. The GOP targeted southern independents. Did independents break more heavily for the GOP in the South in 1994 than previously, while partisans remained loyal to their standard bearer? Or, did Republicans display greater loyalty in 1994 than in previous years? Or, is it possible that large numbers of Democrats defected? A potential explanation for the jump in GOP support that requires neither greater loyalty among Republicans nor disloyalty among Democrats would be that Republican identifiers increased.

Moderates are another group more likely to shift toward the GOP in 1994. Since in most districts the Democratic nominee is more liberal than the Republican, liberals will vote Democratic while conservatives support Republicans. Moderate voters are more likely to split their tickets than are their peers who ideologically are less centric (Fiorina 1988; Hill 1991).

Why?

The Republican's Contract with America emphasized changes that Newt Gingrich (R-GA) promised would be initiated quickly if Republicans won a majority. Embedded in these promises were criticisms of the House that had been run by Democrats for 40 years. The trick for Gingrich was to make the Democratic Congress the fall guy and expand the negative evaluations about Congress to encompass Democratic incumbents. To achieve this end it would be necessary to overcome the dichotomy in which voters distrust the institution but love their representative (Fenno 1975).

GOP efforts to nationalize the campaign involved lashing southern Democrats in Congress to their more liberal leaders. While conservative and moderate Democrats had continued to win elections in the South, liberals encountered difficulty triggered by federal enforcement of civil rights (Black and Black 2002). Voters convinced that their local Democratic nominee was cut from the national liberal mold are more likely to vote Republican (Black and Black 1987; Glaser 1996).

A second aspect of nationalizing congressional campaigns focused on President Clinton and his wife to personalize claims that the government was not working as it should and had become not only ineffective but too intrusive. The "Clinton factor" provided an overlay to the phenomenon that midterm House elections, often viewed as referenda on presidential performance, usually result in the president's party losing seats. Retrospective evaluations of the president, impacted by his deficit reduction plan and accompanying tax increases, gun control, health care reform, and the strength of the president's previous election all affect the scope of his party's midterm loss (see also Campbell 1997). Earlier Mann and Wolfinger (1980) observed that the small defections among Democrats who disapproved of President Carter's performance could account for changes in the partisan vote between 1976 and 1978. During his first term, President Clinton's approval ratings in the South were often ten points lower than in other regions. Presidential job approval is examined as a possible correlate of congressional voting.

Health care reform and the way in which the administration's proposals had been mishandled proved particularly 
troubling for President Clinton and his party in 1994. The product, inextricably linked to Hillary Clinton, was widely criticized and ridiculed by partisan foes and special interests such as medical practitioners and the pharmaceutical industry. Fall campaign advertising and Republican candidate speaking points emphasized the Clintons' effort to bring one-seventh of the nation's economy under government control. The traditional resistance of the South to intrusive regulation and large government programs may have helped fuel the anti-Democratic backlash.

The ANES in several years of the 1990s included a question that measured health policy attitudes. Respondents were asked to place themselves on a 7-point scale, ranging from the most liberal support for a government insurance plan to the most conservative support of private insurance plans. Liberal opinion will be classified as responses 1 and 2 , conservative opinion as 6 and 7 , and moderate opinion as a response of 3,4 , or $5 .^{2}$

Attitudes touching on race relations have been at or near the surface of southern politics for decades. V. O. Key (1949) argued that at the core of the region's politics lay the "Negro question." Race is often cited as a continuing factor that structures white southern voting behavior (Giles and Buckner 1995). Sundquist (1983) notes that perceived Democratic support for affirmative action programs helped GOP candidates in the South. Black and Black (1992) disentangle this phenomenon. Their analysis of white voting for president concludes that the shift of southern whites away from the Democratic Party and ultimately toward the GOP is a product of southern economic conservatism, combined with concerns about the role of blacks in the community. Major federal programs to help the poor-disproportionately blacks in the South-are difficult for some conservative southerners to accept. Making governmental aid to blacks more troublesome for some southerners was the protracted struggle surrounding redistricting in states where majority-minority districts were drawn after the 1990 census.

To tap white racial attitudes, we use a question found on every ANES since 1980 that provides a 7-point scale on which the most liberal option is "government should make every effort to help blacks" and the conservative anchor is "government should make no special effort to help blacks." Dividing responses into liberal (a response of 1-2), moderate (3-5) or conservative (response of 6-7), reveals partisan divisions on racial issues. Every year the Republican congressional vote has been higher among racial conservatives than racial liberals. ${ }^{3}$

We also examine feelings regarding Christian fundamentalists. The South has historically been one of the most

\footnotetext{
2 In the 2000 NES the scale was collapsed into a five-point one. The corresponding measures are: responses of 1 and 2 are the most conservative, responses of 3 are moderate, and responses of 4 and 5 are the most liberal.

3 In 2000 the NES changed this item to a scale of five. For that year, responses of lor 2 will be liberal, 3 will be moderate, and 4 or 5 will be conservative.
}

traditionally religious regions of the country and the nation's largest Protestant denomination, the evangelical Southern Baptist Convention is rooted there (Guth 1996: 147). Exit polls show Christian fundamentalists to be the core GOP constituency in the South (Black and Black 2002) and attitudes about this group are related to support for Republican nominees. The ANES has frequently used a feeling thermometer on Christian fundamentalists to measure respondents' attitudes in this area.

Finally, we examine attitudes on homosexuals serving in the military. As a presidential candidate, Clinton pledged to address the ban on gays in the military and sought to do so in the first month of his presidency. Clinton, however, was forced to compromise on this issue and was not able to simply lift the ban. Senator Sam Nunn (D-GA) played a key role in the resulting "don't ask, don't tell" policy (Wigton 1996: 477). Being home to a disproportionate number of military installations, this issue reverberated in the South unlike in any other region of the United States. In the 1990s, the ANES began asking respondents whether they believe homosexuals should be allowed to serve in the armed forces.

\section{FINDINGS}

Compared to previous years, GOP support in 1994 increases dramatically in many categories. After 1994, Republicans attracted broad-based support among white voters in the South; Republican support that has been consolidated and sustained through the end of the decade. In 1994 about 64 percent of the region's white voters reported backing the GOP House nominee, a jump of almost 16 percentage points over the previous election. By 2000, 70 percent of white southerners reported they voted for a GOP congressional candidate.

Beginning in 1994, white southerners' presidential and congressional voting became more consistent in terms of partisanship as they reconciled partisan identification, ideology, and vote choice. Under these circumstances, indicators that previously acted independent of ideology or partisanship will instead affect the vote via ideology and partisanship.

Gender

In 1990, women were 26 points more likely to vote Democratic in congressional races; by 1992, the gender gap had closed to one point with fewer than half of white males voting Republican. A sizable jump in GOP support occurred for both sexes in 1994. Despite an almost ten-point gender gap in 1994, the election marks the first time that a majority of both men and women supported Republican House candidates. In every election thereafter, both genders give a substantial majority of their vote to the GOP. The gender gap shrinks to a mere one point in 1996 and three points in1998 (when more women than men vote Republican). A nine-point gap returns in 2000. 
$\equiv$ TABLE 1

Republican Support Among Categories of White Congressional Voters in the South, 1980-2000

\begin{tabular}{|c|c|c|c|c|c|c|c|c|c|c|c|}
\hline & 1980 & 1982 & 1984 & 1986 & 1988 & 1990 & 1992 & 1994 & 1996 & 1998 & 2000 \\
\hline Total & 40.3 & 42.0 & 42.3 & 35.8 & 32.2 & 41.7 & 48.4 & 64.2 & 62.8 & 68.4 & 70.8 \\
\hline Men & 36.4 & 37.5 & 46.2 & 44.6 & 39.2 & 54.5 & 48.8 & 69.5 & 63.5 & 67.5 & 76.1 \\
\hline Women & 54.9 & 46.3 & 39.3 & 29.5 & 26.1 & 28.8 & 47.8 & 59.8 & 62.5 & 70.2 & 66.7 \\
\hline \multicolumn{12}{|l|}{ Family Income } \\
\hline$<\$ 15,000$ & - & - & - & - & - & - & 32.2 & 52.4 & 51.5 & 37.5 & 71.4 \\
\hline$\$ 15-24,999$ & - & - & - & - & - & - & 38.1 & 22.7 & 37.1 & $44.4^{*}$ & 73.7 \\
\hline$\$ 25-49,999$ & - & - & - & - & - & - & 54.9 & 63.2 & 65.6 & 69.6 & 56.5 \\
\hline$\$ 50,000>$ & - & - & - & - & - & - & 63.4 & 80.0 & 73.1 & 83.0 & 78.3 \\
\hline \multicolumn{12}{|l|}{ Education } \\
\hline Not H.S. Grad & 21.6 & 25.0 & 32.7 & 18.2 & 21.1 & 35.2 & 28.1 & 31.6 & 34.8 & $55.6^{*}$ & 63.6 \\
\hline H.S. Grad & 54.0 & 40.0 & 43.4 & 28.9 & 30.4 & 34.2 & 44.8 & 58.5 & 54.5 & 60.0 & 73.2 \\
\hline Some College & 32.5 & 40.0 & 48.1 & 53.3 & 35.3 & 52.2 & 56.3 & 64.3 & 68.8 & 65.4 & 73.5 \\
\hline College Grad & 36.4 & 61.1 & 44.4 & 36.4 & 39.1 & 42.3 & 57.6 & 76.7 & 73.8 & 81.8 & 71.7 \\
\hline Postgraduate & 56.0 & 41.0 & 44.4 & 42.9 & 37.5 & 63.6 & 40.0 & 68.6 & 70.3 & 81.8 & 58.8 \\
\hline \multicolumn{12}{|l|}{ Age } \\
\hline $18-29$ & 27.3 & 55.0 & 40.4 & 30.0 & 24.2 & 30.0 & 50.0 & 65.0 & 57.1 & 53.8 & 80.0 \\
\hline $30-44$ & 52.9 & 50.0 & 41.0 & 42.9 & 36.4 & 45.7 & 54.0 & 69.1 & 69.6 & 83.3 & 69.6 \\
\hline $45-64$ & 32.7 & 38.3 & 46.3 & 39.5 & 35.5 & 52.3 & 45.8 & 66.1 & 61.7 & 70.3 & 71.0 \\
\hline 65 and over & 42.2 & 31.4 & 40.8 & 25.6 & 25.0 & 30.3 & 38.5 & 54.5 & 57.9 & 58.3 & 64.5 \\
\hline Democrats & 27.1 & 22.4 & 25.0 & 10.0 & 18.2 & 20.7 & 16.7 & 22.9 & 28.0 & 34.3 & 36.4 \\
\hline Republicans & 64.2 & 70.0 & 65.7 & 57.1 & 56.3 & 74.0 & 77.1 & 91.6 & 89.2 & 93.2 & 89.3 \\
\hline Independents & 70.0 & 56.8 & 45.7 & 45.8 & 25.8 & 48.9 & 51.0 & 74.6 & 65.7 & 77.8 & 65.5 \\
\hline Liberals & 19.0 & 40.0 & 37.0 & 12.5 & 16.7 & 43.4 & 27.1 & 17.9 & 26.8 & $30.0 *$ & 41.9 \\
\hline Moderates & 31.9 & 40.0 & 29.2 & 27.0 & 21.4 & 40.0 & 50.8 & 58.1 & 50.0 & 66.7 & 63.6 \\
\hline Conservatives & 51.8 & 55.9 & 58.0 & 50.9 & 40.3 & 50.0 & 67.3 & 83.9 & 82.7 & 88.0 & 84.0 \\
\hline \multicolumn{12}{|l|}{ Presidential Job Approval } \\
\hline Approve & $23.7^{* *}$ & 62.8 & 54.0 & 47.1 & 40.0 & 48.4 & 63.8 & $37.5^{* *}$ & $45.5^{* *}$ & $56.09 * *$ & $53.3 * *$ \\
\hline Disapprove & 45.5 & 19.4 & 14.9 & 14.9 & 16.1 & 27.0 & 31.4 & 80.8 & 86.8 & 86.5 & 86.4 \\
\hline \multicolumn{12}{|l|}{ Congressional Approval } \\
\hline Approve & 38.5 & 39.7 & 37.2 & 31.3 & 27.7 & 44.7 & 31.0 & 41.8 & 65.4 & 78.0 & 73.9 \\
\hline Disapprove & 39.3 & 47.5 & 50.5 & 43.9 & 43.1 & 45.0 & 54.7 & 72.3 & 57.0 & 59.6 & 67.1 \\
\hline \multicolumn{12}{|l|}{ Health Policy } \\
\hline $\begin{array}{l}\text { Guarantee } \\
\text { Private }\end{array}$ & - & - & - & - & - & - & 27.0 & 36.1 & 42.1 & - & 65.5 \\
\hline $\begin{array}{l}\text { Insurance } \\
\text { Somewhere }\end{array}$ & - & - & - & - & - & - & 58.3 & 84.6 & 86.4 & - & 77.3 \\
\hline Between & - & - & - & - & - & - & 56.9 & 61.8 & 58.7 & - & 66.7 \\
\hline $\begin{array}{l}\text { Attitude about Government } \\
\text { Aid to Blacks }\end{array}$ & & & & & & & & & & & \\
\hline Make every effort to help & $0.0 *$ & $15.4^{*}$ & 37.5 & $12.5^{*}$ & $9.1 *$ & $9.1^{*}$ & $15.8^{*}$ & $50.0 *$ & $44.4^{*}$ & $27.3 *$ & $33.3 *$ \\
\hline No special effort to help & 41.5 & 43.1 & 53.3 & 35.0 & 40.8 & 45.3 & 57.9 & 74.7 & 80.8 & 94.1 & 78.7 \\
\hline Something between & 43.8 & 50.0 & 40.1 & 38.6 & 19.5 & 49.1 & 45.1 & 60.6 & 52.4 & 67.4 & 64.5 \\
\hline $\begin{array}{l}\text { Homosexuals in the } \\
\text { Armed Forces? }\end{array}$ & & & & & & & & & & & \\
\hline Yes & - & - & - & - & - & - & 38.1 & 53.2 & 56.6 & - & 63.3 \\
\hline No & - & - & - & - & - & - & 60.0 & 82.1 & 73.7 & - & 87.0 \\
\hline
\end{tabular}


TABLE 1 (continued)

\begin{tabular}{llllllllllll}
\hline & 1980 & 1982 & 1984 & 1986 & 1988 & 1990 & 1992 & 1994 & 1996 & 1998 & 2000 \\
\hline $\begin{array}{l}\text { Feeling Thermometer- } \\
\text { Christian Fundamentalists }\end{array}$ & & & & & & & & & & & \\
$0-49$ & - & - & - & - & - & - & 41.9 & 51.9 & 59.7 & 55.6 & 66.0 \\
$50-69$ & - & - & - & - & - & - & 51.2 & 67.7 & 63.0 & 78.6 & 64.3 \\
$70-84$ & - & - & - & - & - & - & 45.0 & 55.2 & 59.4 & 71.4 & 86.4 \\
$85-100$ & - & - & - & - & - & - & 54.7 & 74.6 & 71.4 & 70.0 & 100.0 \\
\hline
\end{tabular}

Data were obtained from various National Election Studies from 1980-2000.

*Fewer than five respondents in cell.

**Democratic presidents

Income Level

Enthusiasm for Gingrich's minions in 1994 did not spread equally across economic groups. Only whites whose annual family incomes exceeded $\$ 25,000$ gave strong support to Republicans. In contrast, almost three in four voters in the $\$ 15,000$ - \$24,999 category went Democratic, while Republicans held their own among the poorest group taking roughly half the vote. The largest increase in GOP support from 1992 to 1994 come among the poorest whites. By the end of the decade, more than 70 percent of those making less than $\$ 25,000$ supported GOP congressional candidates and all income categories in 2000 give majority support to the GOP.

\section{Education Level}

Table 1 indicates that in 1988, no education level awarded even 40 percent of its congressional vote to the GOP. By 1998, all education categories gave majority support to Republicans. Increased GOP support in 1994 came in all but the least educated category. In 1994, except for the best-educated whites, the longer one had been in school the more likely to vote Republican. Only high school dropouts preferred Democrats, and this group made up less than a tenth of the electorate. By 2000, the best educated were the least likely to vote Republican, though a majority still supported the GOP.

\section{Age Cohorts}

Since 1988 all age groups have become more supportive of Republicans. The youngest voters tripled their support from 1988-2000 while other age groups at least doubled their support of the GOP during the same time period. Republican strength reached unprecedented levels among all age groups in 1994 and, in an across-the-board increase, for the first time, captured majorities of all four age groups in Table 1. The most supportive voters were the Baby Boomers 30 to 44 years old, more than two-thirds of whom voted Republican. Even the oldest group, those most likely to remember the Solid Democratic South, gave Republicans a 4:3 advantage. In subsequent elections, GOP candidates continued winning a majority of all age groups.
Partisanship

Republicans in 1994 received near unanimous support (91.6 percent) from voters who identified with the GOP. Republicans had never been more united in casting party-line ballots for the House. The 1994 uptick in GOP support among Independents (23.6 points) outpaced that of Republican identifiers. Democratic identifiers maintained a high level of support for their own party candidates with more than 75 percent voting for their party's nominee in 1994. This support, however, represents a six-point shift toward GOP candidates from the previous election. In subsequent elections, Republican candidate support from Republican identifiers oscillated between 89 percent and 93 percent, while between 65 percent and 78 percent of Independents cast GOP ballots. In the last three elections about one-third of white Democratic Party identifiers balloted for the GOP.

GOP candidates reaped a sizable increase in support from Independents and also improved their performance with Republicans in the 1994 elections and after. Support from Democrats also increased, but less than from Independents and Republicans. The choices made by Independents were almost equidistant between identifiers with the two parties in 1990 and 1992, but since 1994 they have voted much more like Republicans than Democrats.

Ideology

Ideology was not unrelated to vote choice in 1990 but became strongly related in 1992 and strengthened in 1994 as conservatives became more committed to the GOP and liberals united in supporting Democrats. Moderates, whose voting behavior had often been almost indistinguishable from that of liberals in the 1980s, swung toward the GOP in 1994. Prior to 1992, conservatives had never cast more than 60 percent of their votes for a Republican and moderates had not exceeded 40 percent GOP support. In 1994, Republicans drew the votes of 84 percent of the conservatives and 58 percent of the moderates.

Democratic candidates polled especially well among liberals, getting about 80 percent of their votes in 1994. The problem faced by Democrats was that only one in six white southerners fell into the liberal category. By contrast, more than 
sixty percent of the southern white electorate classified itself as conservative. Moderates, who outnumbered liberals by 50 percent, went for Republicans by a 3:2 margin. The GOP advantage among moderates lapsed in1996, though the falloff of moderate GOP ballots was in part compensated by an increase in liberals casting GOP votes. In 2000, most white moderates disappeared from the ANES (only 7.1 percent of identifiers), leaving a predominantly conservative southern white electorate that votes Republican (five times in six), and a minority of liberals who vote Democratic for Congress (three times in five). Overall, if one estimates the proportion of all ballots cast in 2000, 55 percent of southern congressional votes were conservatives casting GOP ballots, while only 16 percent were liberals casting Democratic ballots. ${ }^{4}$

The relationship between respondent perceptions of the ideological position of congressional candidates and voting changed. Black and Black (1986) suggested that Democrats continued to win southern congressional seats by portraying themselves as moderates or conservatives. Of the respondents willing to assign an ideological label to Democratic candidates in 1990, three-fifths saw them as moderate or conservative and Democrats ran well with these voters. Four years later, more than half the voters saw their Democratic nominee as liberal and fewer than one in five pinned the conservative label on the Democrat. In 1994, southern whites' voting decisions were strongly linked to their perception of the Democrat's ideology with Democrats running well among voters who believed them to be conservative but rejected by a 3:2 margin by voters who saw them as liberal. In contrast, no relationship existed between voters' perceptions of the ideological placement of Republican nominees and willingness to cast ballots for them. While three-fourths of the Republican candidates were seen as conservative (and 77 percent of these voters backed the Republican), even voters who perceived the GOP nominee to be moderate or liberal cast more than two of three ballots for the Republican.

\section{Congressional and Presidential Approval}

A variety of recent political science studies reveal that the general approval of the institution of Congress affects vote choice (Finocchiaro, 2003). This is a change from previous expectations (i.e, Fenno 1975) which find a degree of independence between the love for congressmen and the hatred for Congress. Attitudes about Congress relate strongly to 1994 voting behavior. Democrats corralled almost 60 percent of the vote of those who approved of Congress while more

\footnotetext{
${ }^{4}$ In 2000, the proportion of congressional ballots, by ideology, is as follows: Liberal voting Republican: 11.7 percent; Moderate voting Republican: 4.5 percent; Conservative voting Republican: 54.5 percent; Liberal voting Democratic: 16.2 percent; Moderate voting Democratic: 2.6 percent; Conservative voting Democratic: 10.4 percent. There are about the same number of Republican-voting Liberals as Democratic-voting Conservatives. Republicans still have a 2:1 advantage among the small class of moderates.
}

than 70 percent of the critics tried to elect a Republican. The impact of attitudes about Congress shifted dramatically from 1990 to 1994. In 1990, roughly the same number of those approving and disapproving of Congress's performance gave their vote to GOP congressional candidates. In 1992, those who disapproved of Congress were 24 points more likely to vote GOP; by 1994, the disapproving/approving gap was 31 points The phenomenon of majority support for Democrats, regardless of how Congress was evaluated persisted throughout the period of Democratic dominance in Table 1 save for 1984 when critics voted Republican by the narrowest margin. The 23.7 point difference in voting patterns registered in 1992 was among the largest when Democrats ruled the House and in retrospect was a precursor for 1994 when disapproval became very strongly associated with a Republican vote. More recently a majority of those who approve and those who disapprove of Congress vote for the GOP although Republicans do somewhat better among voters holding positive evaluations. Gingrich and the Republicans succeeded in capitalizing on disapproval of Congress in 1994.

The congressional preferences of southern whites has been related to evaluations of presidential performance with Republicans running best among critics when a Democrat occupied the White House and with the pattern reversing during the tenure of a Republican chief executive. Thus it was expected that Clinton critics would be more likely to vote for Republican congressional candidates in 1994. Contributing to the GOP surge were three in eight Clinton fans who nonetheless voted Republican along with four-fifths of those who evaluated the president negatively. The remarkable cohesion of Clinton's foes persisted throughout his presidency but the relationship between evaluations of his job performance and congressional voting weakened as even most of his backers supported Republicans for Congress by 1998 .

\section{Policy Issues}

The three policy areas examined also sort out House voting preferences in expected ways. Health care assumed special significance in light of the Clinton proposal to expand coverage to millions lacking health insurance and the harsh reaction that torpedoed the plan. The distinction on the health care issue was especially striking as Republicans got a third of the vote among those who favored government-guaranteed health care in 1994 while attracting more than twice that level of support from among voters who favored private insurance and the jump in GOP support came chiefly from the latter group. This same pattern is also present in 1996, but by 2000 Republican congressional candidates are carrying nearly two-thirds support across all dimensions of the health issue.

Given the unique role of race in southern politics (Key 1949), the second policy area considered involved government assistance for African Americans. Very few southern whites favored aggressive government efforts on behalf of blacks. The 1994 congressional elections saw GOP support 
rise among voters regardless of their attitudes about efforts to aid blacks. The level of Republican support among racial conservatives in 1994 (74.7 percent) resembled the level of support for Reagan and Bush by racial conservatives in 1980, 1984, and 1988 (68.2 percent, 74.6 percent, and 70.7 percent, respectively). Racial conservatives voted more heavily Republican for the House in 1994 than for president in 1992 (59.9 percent), or 1996 (67 percent). By 2000, racial conservative voting behavior for Republican House and presidential candidates still favored congressional candidates but was only separated by about 6 points (78.7 and 72.9, respectively).

Disaffection with congressional Democrats ran deeper than the fundamental, underlying issues of race. Racial moderates start moving toward the Republican party earlier. From 1980-1988 Republican congressional candidates pulled an average of 38.6 percent of the racial moderate vote. This jumped to 49.1 percent in 1990, 48.3 percent in 1992, and 60.6 percent in 1994.

The final policy issue considered is the status of homosexuals in the military, an issue that came to the forefront in the 1990s. Those responding that they did not favor allowing homosexuals to serve in the military gave strong majority support to Republican House candidates. In 1992, the first year the question was asked, there was a clear pattern with those favoring gays serving in the armed forces giving 62 percent of their support to Democratic House candidates while those responding negatively support Republican House candidates by a similar margin. Although in 1994, both categories of respondents gave majority support to Republican candidates, the gap between the two categories' level of support is the largest at almost 30 points.

\section{Fundamentalist Support}

Voters with the most positive attitudes about Christian fundamentalists, i.e., those who scored Christian fundamentalists at 85 or above on the 100 point feeling thermometer, voted Republican by a 3:1 ratio in 1994 almost a 20 point increase over the previous year. Even those least positive about fundamentalists, i.e., scores below 50 , gave Republicans half their ballots but had a smaller increase from 1992. While the strength of this relationship varies for the subsequent elections, by 2000 an even two-thirds of those with negative feelings towards the Christian Right pulled the GOP lever while the most strident supporters of the Christian Right are uniform in their congressional preference for Republicans.

\section{4: An Historic Election}

Only two categories in 1994, ideological liberals and those with incomes of $\$ 15,000-\$ 24,999$, did not increase their 1992 level of support for House Republican candidates. In 1994 GOP backing in most categories of voters reached historic highs. Those highs, however, would be surpassed for many in subsequent elections, especially 1998 and 2000, which further cemented GOP congressional support in the South. The increased support for GOP members of the House of Representatives from 1994 to 2000 reflects, to some extent the power of incumbency.

While Table 1 shows a general shift toward the GOP in 1994, not all categories moved sufficiently to account for the more than 15-point Republican increase. Republicans chalked up their greatest gains among those with a postgraduate education (28.6 points), Independents (23.6 points), those holding conservative attitudes on health policy (26.3 points), those disapproving of gays in the military (22.1 points), men (20.7 points), the lowest income category (20.2 points), and those aged 45-64 (20.3 points). Thus, GOP congressional nominees made headway among groups that one would expect to favor the party such as those holding more conservative policy attitudes but they also made advances among the key swing group of Independents. They even improved their standing among the lowest income category, often an important element of the Democratic coalition.

\section{Multivariate Analysis}

The descriptive analysis above indicated competing explanations for the level of Republican congressional voting in 1994. That analysis also indicated changes in the potential predictors of congressional voting between 1992, when Republicans won 50 southern seats, and 1994, when they won 66 southern seats. It also illustrates the consolidation of Republican voting among southern whites as congressional voting behavior finally came into alignment with presidential voting behavior. In 1992, a majority of white southern voters were still casting ballots for Democratic congressional nominees. By 1994, this long-standing pattern was reversed.

The dependent variable in the multivariate analysis is the vote for members of Congress, coded 1 if a voter chose a Republican and 0 otherwise. The explanatory variables include all of the potentially significant predictors discussed above, and fall into four categories: (1) personal political behaviors, such as party identification and personal ideology; (2) political-presidential and congressional evaluations; (3) attitudinal variables about Christian fundamentalists, ideology, and issue positions such as on race relations, health care, or gays in the military; and (4) personal characteristics, such as gender, age, income, and education. The description of the coding of each variable appears in the Appendix. Because the dependent variable is dichotomous, logistic regression is used.

As indicated in the first column of Table 2, congressional votes of white southerners in 1992 were driven by party identification and negative feelings on homosexuals serving in the armed forces. By 1994, however, votes are solely driven by partisan identification and feelings on gays serving in the military is no longer a driving factor. In fact, although not statistically significant, the parameter is not in the expected direction. The multivariate model verifies our 
$\equiv$ TABLE 2

Logistic Regression Estimates of Southern White Congressional Voting

\begin{tabular}{|c|c|c|c|c|c|c|}
\hline Variable & 1992 & $1994 a^{* *}$ & $1994^{\mathrm{b} * *}$ & 1996 & 1998 & 2000 \\
\hline Constant & -1.405 & -11.957 & -5.775 & -8.991 & -7.453 & -3.770 \\
\hline Republican ID & $\begin{array}{c}.409(.135)^{*} \\
1.505\end{array}$ & $\begin{array}{c}1.627(.517)^{*} \\
5.090\end{array}$ & $\begin{array}{c}.755(167)^{*} \\
2.127\end{array}$ & $\begin{array}{c}.539(.147)^{*} \\
1.715\end{array}$ & $\begin{array}{c}.458(.204)^{*} \\
1.581\end{array}$ & $\begin{array}{c}.564(.186)^{*} \\
1.758\end{array}$ \\
\hline Christian Fund. & $\begin{array}{c}-.011(.010) \\
.989\end{array}$ & $\begin{array}{c}.004(.025) \\
1.004\end{array}$ & $\begin{array}{c}.006(.010) \\
1.006\end{array}$ & $\begin{array}{c}.023(.010) \\
1.023\end{array}$ & $\begin{array}{c}.001(.016) \\
1.001\end{array}$ & $\begin{array}{c}.019(.012) \\
1.020\end{array}$ \\
\hline Conservative Ideology & $\begin{array}{c}.105(.198) \\
1.111\end{array}$ & $\begin{array}{c}.202(.481) \\
1.224\end{array}$ & $\begin{array}{c}.251(.246) \\
1.285\end{array}$ & $\begin{array}{c}.287(.220) \\
1.332\end{array}$ & $\begin{array}{c}.017(.384) \\
1.017\end{array}$ & $\begin{array}{c}-.046(.236) \\
.955\end{array}$ \\
\hline Congressional Approval & $\begin{array}{c}-.245(.516) \\
.783\end{array}$ & $\begin{array}{c}.176(1.207) \\
1.192\end{array}$ & $\begin{array}{c}-.021(.972) \\
.979\end{array}$ & $\begin{array}{c}-.152(.436) \\
.859\end{array}$ & $\begin{array}{c}.952(.789) \\
2.590\end{array}$ & $\begin{array}{c}-.014(.551) \\
.986\end{array}$ \\
\hline Pres. Job Approval & $\begin{array}{c}.776(.463) \\
2.173\end{array}$ & $\begin{array}{c}.153(1.499) \\
1.165\end{array}$ & $\begin{array}{c}-.670(.599) \\
.512\end{array}$ & $\begin{array}{c}-.289(.546) \\
.749\end{array}$ & $\begin{array}{c}.245(.929) \\
1.277\end{array}$ & $\begin{array}{c}-.110(.742) \\
.895\end{array}$ \\
\hline Racial Assistance Conservativism & $\begin{array}{c}.022(.225) \\
1.022\end{array}$ & $\begin{array}{c}-.100(.770) \\
.905\end{array}$ & $\begin{array}{c}-.124(.340) \\
.884\end{array}$ & $\begin{array}{c}.233(.265) \\
1.263\end{array}$ & $\begin{array}{c}1.299(.630)^{*} \\
3.665\end{array}$ & $\begin{array}{c}.380(.304) \\
1.463\end{array}$ \\
\hline Health Policy Conservativism & $\begin{array}{c}.012(.218) \\
1.012\end{array}$ & $\begin{array}{c}-.449(.555) \\
.638\end{array}$ & $\begin{array}{c}-.150(.273) \\
.861\end{array}$ & $\begin{array}{c}.199(.282) \\
1.221\end{array}$ & - & $\begin{array}{c}.020(.221) \\
1.020\end{array}$ \\
\hline Gender & $\begin{array}{c}.276(.420) \\
1.318\end{array}$ & $\begin{array}{c}2.706(1.531) \\
14.975\end{array}$ & $\begin{array}{c}.580(.547) \\
1.787\end{array}$ & $\begin{array}{c}.563(.463) \\
1.756\end{array}$ & $\begin{array}{c}.148(.719) \\
1.160\end{array}$ & $\begin{array}{c}-.029(.596) \\
.972\end{array}$ \\
\hline Income & $\begin{array}{c}.347(.206) \\
1.415\end{array}$ & $\begin{array}{c}.744(.520) \\
2.104\end{array}$ & $\begin{array}{c}.497(.292) \\
1.643\end{array}$ & $\begin{array}{c}-.209(.225) \\
.812\end{array}$ & $\begin{array}{c}.371(.400) \\
1.449\end{array}$ & $\begin{array}{c}-.040(.270) \\
.961\end{array}$ \\
\hline Education & $\begin{array}{c}-.146(.148) \\
.864\end{array}$ & $\begin{array}{c}-.295(.414) \\
.745\end{array}$ & $\begin{array}{c}.050(.184) \\
1.051\end{array}$ & $\begin{array}{c}.245(.154) \\
1.278\end{array}$ & $\begin{array}{c}.292(.277) \\
1.339\end{array}$ & $\begin{array}{c}.156(.203) \\
1.169\end{array}$ \\
\hline Age & $\begin{array}{c}-.015(.014) \\
.985\end{array}$ & $\begin{array}{c}.032(.031) \\
1.032\end{array}$ & $\begin{array}{c}.013(.016) \\
1.013\end{array}$ & $\begin{array}{c}.035(.016)^{*} \\
1.036\end{array}$ & $\begin{array}{c}-.026(.024) \\
.975\end{array}$ & $\begin{array}{c}.000(.019) \\
1.0\end{array}$ \\
\hline Gays in Military & $\begin{array}{c}-1.151(.476)^{*} \\
.316\end{array}$ & $\begin{array}{c}.992(1.630) \\
2.697\end{array}$ & - & $\begin{array}{c}1.061(.552) \\
2.889\end{array}$ & - & $\begin{array}{c}-.739(.703) \\
.478\end{array}$ \\
\hline $\begin{array}{l}\text { Log-likelihood } \\
\text { Null Prediction } \\
\text { \% Correct Prediction } \\
\text { PRE }\end{array}$ & $\begin{array}{l}66.837 \\
53.846 \\
76.923 \\
50.000\end{array}$ & $\begin{array}{l}55.482 \\
64.384 \\
89.041 \\
69.230\end{array}$ & $\begin{array}{l}93.567 \\
66.250 \\
85.000 \\
55.556\end{array}$ & $\begin{array}{l}80.752 \\
64.118 \\
80.588 \\
45.900\end{array}$ & $\begin{array}{l}36.685 \\
67.568 \\
82.432 \\
45.831\end{array}$ & $\begin{array}{l}43.620 \\
67.257 \\
79.646 \\
37.837\end{array}$ \\
\hline Valid N & 169 & 73 & 160 & 170 & 74 & 113 \\
\hline
\end{tabular}

Standard errors in parentheses. Change in odds ratio below parameter estimates. An analysis of variance inflation factors for the independent variables revealed no siginficant multicollinearity in the models for any of the years.

$* \mathrm{p}<.05$

**The question regarding attitudes on homosexuals serving in the military in the 1994 ANES is from the 1993 pilot study and as such was not asked of all respondents. The inclusion of this variable substantially reduces the number of cases available for analysiswith our model. A Chow test was conducted for those with a response on this question and those without. $\mathrm{F}=1.617$; critical $\mathrm{F}_{(11,136)}=1.87$.

suspicion that the 1994 vote was more than the backlash of the angry white man as gender is not a significant predictor. Nor were attitudes about health coverage or Christian fundamentalists significant factors in the congressional vote. In the subsequent three elections, only party identification is consistent as a predictor.
What can we say from these models? The analysis indicates that three of the myths of the 1994 election-the angry white male backlash, the residual negative effects of the "don't ask, don't tell" policy, and the Christian Coalition mobilization-are less important than widely assumed. The critical mobilization of 1994 was not men, those opposed to 
gays serving in the military, or those with positive feelings regarding Christian fundamentalists. The critical factor in the 1994 election was that the voters began behaving in a way that corresponded with their party identification, something that southern white voters had not done consistently down-ticket before the 1990s.

The balance of the 1990s is a story of partisan consolidation aided by the lure of incumbency. Demographic predictors largely fail significance tests in predicting congressional vote choice. Southern congressional elections have become defined almost entirely in party terms for southern whites by the end of the decade, and the party of choice is the GOP.

\section{CONCLUSIONS}

The GOP triumph in 1994 was thought to be fueled by angry white males and the Christian Right, both mobilized, at least in part, by dissatisfaction over the change in policy on the status of homosexuals serving in the armed forces. We find little evidence of these factors being important predictors of vote choice in that election. Specific issues of health care reform and federal policy toward African Americans also failed to be related to southern whites' vote preferences, and as others have found, these issues are far less important than general ideology in explaining party identification. Those factors do not show any persistent influence subsequent to 1994, although racial conservatism is significant in the 1998 elections. To the extent that issues drove the 1994 election, an issue effect was likely through more generally held beliefs acting through partisanship. The critical factor in 1994 was white southerners finally voting in ways consistent with their partisan identification of House candidates.

Party identification contributed to explaining congressional voting patterns as Republican identifiers rallied to GOP nominees in record numbers. The long-term effect was to recast white congressional voting on a strong, partisan dimension, free of secondary predictors. The structure of the congressional electorate took on a coherent shape, resembling the shape of the presidential vote. This relationship is reflected in recent aggregate election results. George W. Bush won all but five of the 73 congressional districts that elected Republicans in 2000. ${ }^{5}$ Bush also carried 18 of the 52 districts held by Democrats after November 2000. Five of these districts are in the Deep South (AL-1, LA-7, GA-2, MS-5, and SC-5) and another eight are in Texas (CDs $1,2,4,9,10,11,17$, and 27). The remaining four are in North Carolina (CDs 2 and 7), Tennessee (CD-6), and Virginia (CD-9). This is a stark contrast to the 1988 election, in which the vast majority of southern congressional districts turned in split decisions, despite a GOP sweep of the region. This result is consistent with the aggregate analysis of Southern GOP development by Hood, Kidd, and Morris (2004: 90), in which the authors conclude that in the South, "political factors begat political change."

How does one summarize the state of southern white congressional voting in the 1990s? Across a variety of factors that historically distinguished Southern Republicanism, whites are now overwhelmingly Republican in their congressional voting behavior. The events of 1994 represent a significant intervention in the southern electorate that propelled congressional and presidential preferences into closer coherence along party and ideological lines. Then, through the remainder of the decade, much of the southern, white electorate converted to the GOP in congressional vote choice. This conversion and stabilization of southern white preferences is the endgame of the southern realignment, the period in which party preferences drive partisan choices and do so without significant caveat of the sort used to excuse the previous state of partisan incoherence.

\footnotetext{
${ }^{5}$ Three of these districts were in Florida (CDs 10, 16, 22) and two were in Virginia (CDs 4 and 11).
}

\section{APPENDIX. \\ VARIAbles AND CODING FOR THE Multivariate ANAlysis}

\begin{tabular}{ll}
\hline Variable & Coding \\
\hline Republican Identification & Respondent's self-placement on a seven-point scale, where 1 is strong Democrat and 7 is \\
& strong Republican (recode from v523 in 2000, v339 in 1998, v420 in 1996, v655 in 1994, \\
& v3634 in 1992).
\end{tabular}

Christian Fundamentalism

Conservative Ideology

Congressional Approval
For 1992, 1994, 1996 and 2000: The respondent's feeling thermometer for Christian Fundamentalists 1992 v5338, 1994 v315, 1996 v1038, 2000 v1317. For 1998: The respondent's feeling thermometer for Religious Right v263.

Respondent's self-placement on a seven-point scale, where 1 is most liberal and 7 most conservative (2000 v446; 1998 v399; 1996 v365; 1994 v839; 1992 v3509).

1 if the respondent approves of the performance of congress, 0 otherwise (recode from v356 in 2000, v236 in 1998, v270 in 1996, v320 in 1994, v5949 in 1992) 


\begin{tabular}{ll}
\hline Variable & Coding \\
\hline Presidential Approval & $\begin{array}{l}1 \text { if the respondent approves of the performance of the president, } 0 \text { otherwise (recode } \\
\text { from v339 in 2000, v216 in 1998, v295 in 1996, v201 in 1994, v3319 in 1992). }\end{array}$
\end{tabular}

Racial Assistance

Respondent's self-placement on a five point scale, where 1 Conservatism indicates "Government should help blacks" (most liberal) and 5 indicates blacks should help themselves" (most conservative) (2000 v645; recode from v462 in 1998, v487in 1996, v936 in1994, v3724 in1992)

Health Policy Conservatism

Respondent's self-placement on a five point scale ranging from "Government Insurance plan" (most liberal) to "private insurance plan" (most conservative) (2000 v614; recode from v479 in 1996, v950 in 1994, v3716 in 1992)

Gender

Respondent coded 1 if male, 2 if female (2000 v1029; 1998 v672;1996 v66; 1994 v1434; $1992 \mathrm{v} 4201)$

Income

Ordinal measure of family income in 4 categories, ranging from under $\$ 15,000=1 ; 15$, $24,999=2 ; 25,000-49,999=3 ; 50,000$ and $u p=4$ (recode of $2000 \mathrm{v} 997 ; 1998 \mathrm{v} 652$; 1996 v701; 1994 v1404; 1992 v4104)

Education

Seven-point, ordinal measure of respondent education ranging from less than 8 years $=1$ to postgraduate education $=7(2000 \mathrm{v} 913 ; 1998 \mathrm{v} 577 ; 1996 \mathrm{v} 610 ; 1994 \mathrm{v} 1209 ; 1992$ v3908)

Age

In years (2000 v908; 1998 v572; 1996 v605; 1994 v1203; 1992 v3903Gays in military 1 if the respondent approves of homosexuals serving in Armed Forces, 0 otherwise (2000 v. $724 ; 1996$ v. $1195 ; 1994$ v. $7329 ; 1992$ v. 5925$)$

\section{REFERENCES}

Aistrup, Joseph A. 1989. "Top-Down Republican Party Development in the South. Paper presented at the annual meeting of the Midwest Political Science Association, Chicago.

1996. The Southern Strategy Revisited. Lexington: University Press of Kentucky.

Abramowitz, Alan I. 1994. "Issue Evolution Reconsidered: Racial Attitudes and Partisanship in the U.S. Electorate." American Journal of Political Science 38: 1-25.

Abramowitz, Alan I., and Saunders, Kyle L. 1998. "Ideological Realignment in the U.S. Electorate." Journal of Politics 60: 634-52.

Balz, Dan, and Ronald Brownstein. 1996. Storming the Gates. Boston, MA: Little, Brown.

Beck, Paul Allen. 1977. "Partisan Dealignment in the Postwar South. American Political Science Review 71 (June): 477-97.

Black, Earl, and Merle Black. 1987. Politics and Society in the South. Cambridge, MA: Harvard.

1992. The Vital South: How Presidents are Elected. Cambridge, MA: Harvard.

2002. The Rise of Southern Republicans. Cambridge, MA: Harvard.

Bullock, Charles S., III. 1988a. "Regional Realignment from an Officeholding Perspective. Journal of Politics 50: 553-74. 1988b. "Creeping Realignment in the South." In Robert H. Swansbrough and David M. Brodsky, eds., The South's New Politics: Realignment and Dealignment. Columbia: University of South Carolina Press.

1993. "The Partisan, Racial, and Gender Makeup of Georgia County Offices." Public Policy Research Series. Athens, GA: Carl Vinson Institute of Government Press.
Campbell, James E. Presidential Pulse of Congressional Elections, 2nd ed. Lexington: University Press of Kentucky.

Farah, Barbara G., and Helmut Norpoth. 1986. "Trends in Partisan Realignment, 1976-1986." Paper presented at the annual meeting of the American Political Science Association. Washington, DC.

Fenno, Richard F., Jr. 1975. "If, As Ralph Nader Says, Congress Is 'the Broken Branch,' How Come We Love Our Congressmen So Much?" In Norman J. Ornstein., ed., Congress in Change. New York: Praeger.

Finocchiaro, Charles J. 2003. "An Institutional View of Congressional Elections: the Impact of Congressional Image on Seat Change in the House." Political Research Quarterly 56: 59-65.

Fiorina, Morris P. 1988. "The Reagan Years: Turning to the Right or Groping Toward the Middle?" In Allan Kornberg and William Mishler, eds., The Resurgence of Conservativism in Anglo-American Democracies. Durham, NC: Duke University.

Gaddie, Ronald Keith. 1997. "Congressional Seat Swings: Revisiting Exposure in House Elections." Political Research Quarterly 50: 675-86.

Gaddie, Ronald Keith, and Charles S. Bullock, III. 2000. Elections to Open Seats in the US House: Where the Action Is. Lanham, MD: Rowman and Littlefield Press.

Giles, Michael W., and Melanie Buckner. 1995. "David Duke and the Electoral Politics of Racial Threat." In John C. Kuzenski; Charles S. Bullock, III; and Ronald Keith Gaddie; eds., David Duke and the Politics of Race in the South. Nashville, Tennessee: Vanderbilt University Press.

Gilmour, John B., and Paul Rothstein. 1993. "Early Republican Retirement: A Cause of Democratic Dominance in the House of Representatives." Legislative Studies Quarterly 18: 345-65. 
Glaser, James M. 1996. Race, Campaign Politics, and the Realignment in the South. New Haven, CT: Yale University Press.

Guth, James L. 1996. "The Bully Pulpit: Southern Baptist Clergy and Political Activism 1980-92.” In John C. Green, James L. Guth, Corwin E. Smidt, and Lyman A. Kellstedt, eds., Religion and the Culture Wars. Lanham, MD: Rowman \& Littlefield.

Hadley, Charles D. 1985. "Dual-Partisan Identification in the South." Journal of Politics 47 (February): 254 - 68.

Hill, Kevin A. 1991. "Waiting for the Millennium, But the Millennium Never Comes: Split Level Voting as a New Political Alignment in the South. Paper presented at the annual meeting of the Southern Political Science Association, Tampa.

Hood, M. V., III, Quentin Kidd, and Irwin L. Morris. 2004. "The Reintroduction of Elephas Maximus to the Southern United States: The Rise of Republican State Parties, 1960 to 2000. American Politics Research 32: 68-101.

Jacobson, Gary C. 1990. Electoral Origins of Divided Government. Coulder, CO: Westview.

Key, V. O. 1949. Southern Politics in State and Nation. New York: Vintage.

1955. "A Theory of Critical Elections." Journal of Politics 17 (February): 3-18.

1959. "Secular Realignment and the Party System." Journal of Politics 21 (February): 198-210.

1966. The Responsible Electorate. Cambridge, MA: Harvard University Press.

Mann, Thomas E., and Raymond Wolfinger E. 1980. "Candidates and Parties in Congressional Elections." American Political Science Review 74: 617-32.

Miller, Warren E., and the National Election Studies. 1991. American National Election Studies Cumulative Data File, 19521992, 1994, and 1996 [Computer File], sixth release. University of Michigan, Center for Political Studies [producer], 1994; Inter-University Consortium for Political and Social Research [distributor]. Ann Arbor, MI.

Miller, Warren, and J. Merrill Shanks. 1996. The New American Voter. Cambridge, MA: Harvard.
Nadeau, Richard, and Harold W. Stanley. 1992 Group Partisanship of Native Southern Whites, 1952-1990. Presented March 5-6, at the Citadel Symposium on Southern Politics, Charleston.

Norpoth, Helmut. 1987. "Under Way and Here to Stay: Party Realignment in the 1980s?" Public Opinion Quarterly 51: 376-91.

Parker, Suzanne L. 1988. "Shifting Party Tides in Florida: Where Have All the Democrats Gone?" In Robert H. Swansbrough and David Brodsky, eds., The South's New Politics, pp. 22-37. Columbia: University of South Carolina Press.

Petrocik, John R. 1981. Party Coalitions: Realignments and Decline of the New Deal Party System. Chicago: University of Chicago Press.

__ 1987. "Realignment: New Party Coalitions and the Nationalization of the South." Journal of Politics 49 (May): 347-75.

Stanley, Harold W. 1988. Southern Partisan Change: Dealignment, Realignment, or Both? Journal of Politics 50 (February): 64-88.

_ 1992. "Southern Republicans in Congress: Have They Fallen and They Can't Get Up?" Social Science Quarterly 73 (March): 136-40.

Stanley, Harold W., and Charles D. Hadley. 1987. "The Southern Presidential Primary: Regional Intentions with National Implication." Publius 17 (Summer): 83-100.

Sundquist, James L. 1983. Dynamics of the Party System: Alignment and Realignment of Political Parties in the United States, rev. ed. Washington, DC: Brookings.

Wigton, Robert C. 1996. "Recent Presidential Experience with Executive Orders." Presidential Studies Quarterly 26 (Spring): 473- 84.

Wolfinger, Ray, and Michael G. Hagen. 1985. "Republican Prospects: Southern Comfort." Public Opinion 8: 8-13.

Received: November 10, 2003

Accepted for Publication: March 3, 2004

cbullock@uga.edu

donna.hoffman@uni.edu

rkgaddie@ou.edu 